\title{
AN OVERVIEW OF MONITORING for RAPTORS IN BULGARIA
}

\section{Pregled monitoringa populacij ptic roparic v Bolgariji}

\author{
Svetoslav Spasov, Volen Arkumarev, Dobromir Dobrev \& Vladimir Dobrev \\ Bulgarian Society for the Protection of Birds / BirdLife Bulgaria, P.O. Box 50, BG-1111 Sofia, Bulgaria, \\ e-mail: svetoslav.spasov@bspb.org
}

Since 1990, nature conservation NGOs are the main players in the running of nation-wide research and monitoring schemes for raptors in Bulgaria. Among them, the Bulgarian Society for the Protection of Birds (BSPB) and Green Balkans are most active, covering the most threatened diurnal raptors in the country. The key species covered by comprehensive monitoring schemes are the Imperial Eagle Aquila heliaca, White-tailed Eagle Haliaeetus albicilla, Egyptian Vulture Neophron percnopterus, Griffon Vulture Gyps fulvus, Black Vulture Aegypius monachus, Saker Falcon Falco cherrug and Red-footed Falcon F. vespertinus. Information on their distribution, numbers, breeding success, productivity, diet, movements etc. is gathered on annual basis. The Buzzard Buteo buteo and Kestrel F. tinnunculus are also regularly monitored at the national level by the Common Bird Monitoring scheme. Distribution of all raptor species has been studied for the purpose of the Atlas of Breeding Birds in Bulgaria. The contemporary satellite telemetry methods revealed important aspects of movements and threats to eagles and vultures from Bulgaria within the country and abroad. Main threats for the raptors in Bulgaria are related to habitat loss, unnatural mortality and disturbance. The main gaps in raptor monitoring in Bulgaria are related to the lack of coverage of most of the diurnal species and owls. There is a strong national and international cooperation in conjunction with the work concerning Imperial Eagle, Egyptian and Griffon Vultures. However, further enhancement of cooperation on other raptor species and issues such as lobbying for implementation of raptor-friendly agricultural practices and enhancement of various economic sectors are needed.

Key words: raptors, monitoring, BSPB, Bulgaria

Ključne besede: ptice roparice, monitoring, BSPB, Bolgarija

\section{Introduction}

So far, 37 diurnal birds of prey have been registered in Bulgaria, 23 of which breed here regularly (BUNARCO 2009). The interest in raptor species of birds has always inspired many scientists and conservationists in Bulgaria (ANgelov 2009). For the 1950-2008 period, more than 120 publications dedicated to the research of raptor species can be found in Bulgarian literature (Mirkov 2009). Till the 1980s, most of the surveys had been done without planning actions for the establishment of a long term conservation strategy. The first targeted conservation activities were carried out in Eastern Rhodopes in the beginning of the 1980s, when supplementary feeding sites, maintained by BSPB, were established (DoBrev et al. 2013). This consequently resulted in the increase of Griffon Vultures' Gyps fulvus population in the Eastern Rhodopes (IANkov \& Profirov i 99i, Demerdzhiev et al. in prep.). Later on, at the beginning of the 1990 s, the BSPB established a regular monitoring of all raptor species inhabiting the Eastern Rhodopes with the support of the Bulgarian-Swiss Biodiversity Conservation Programme (Hristov 200o). In recent years, the raptors research techniques and projects in Bulgaria have gone far beyond the faunistic and purely descriptive studies. New surveys and studies have been introduced, using modern methods such 
as satellite tracking, ecological surveys, habitat selection research, etc. This involved a great deal of international cooperation, which eventually brought new knowledge and information on many aspects of the raptors' ecology and conservation requirements (BSPB 20 io \& 20i i, Demerdzhiev 20i i, Dobrev et al. 20I3, Demerdzhiev et al. in prep.).

\section{Main players}

The Executive Environment Agency (within the Ministry of Environment and Water) is the state authority responsible for biodiversity monitoring in Bulgaria. The Agency has recently established the National Biodiversity Monitoring System specified in the Biodiversity Act. However, there is limited capacity among state organizations to implement comprehensive monitoring schemes due to the small number of experienced fieldworkers and lack of suitable funding. At the moment, only National Parks directorates are providing some data on selected species, but these cover only the park's territories.

The Bulgarian Academy of Science used to play an important role in the autumn migration monitoring and studies (Michev \& Simeonov i98 i). In 1990, this activity was virtually taken over by NGOs and private consultancies dealing with Environmental Impact Assessments.

The Bulgarian Society for the Protection of Birds (BSPB), the BirdLife International's partner in Bulgaria, is the main organization implementing nation-wide raptor monitoring schemes and research. Its activities cover the most threatened priority species and some widespread birds of prey.

Three other nature conservation NGOs, the Green Balkans, Fund for Wild Flora and Fauna (FWFF) and Birds of Prey Protection Society (BPPS), are also implementing regional or local monitoring schemes, mostly focused on captive bred Griffon Vultures that have been introduced to areas away from their native population in the Eastern Rhodopes as part of restocking programme in Bulgaria (GreEn BaLKans 2005, 2006, 2007 \& 20io, Stoynov \& Peshev 20i i, $2012 \& 2013)$.

The BSPB has developed active contacts and cooperation with several countries, mostly with BirdLife International local partners. The main foreign partners are RSPB, MME/BirdLife Hungary, Doğa Dernegi (BirdLife Partner Designate in Turkey), Hellenic Ornithological Society (BirdLife partner in Greece), WWF Greece, Macedonian Ecological Society (MES) and Protection and Preservation of Natural Environment in Albania (PPNEA). BSPB has established contacts and work actively with several African countries in the conservation of migrating raptors such as Egyptian Vulture and Imperial Eagle. (Arkumarev et al. 2012, Dobrev et al 20 I 2).

Data collected as part of the monitoring schemes and research in various raptor species is used mainly by NGOs and private companies in environmental impact assessments of investment proposals within Natura 2000 sites or other areas with importance for birds of prey. State authorities have occasionally requested some data on distribution and number of some birds of prey, but the usage of the available information is scanty.

\section{National coverage}

The BSPB considers seven diurnal raptor species as priority species for monitoring and they are covered at the national level by comprehensive monitoring schemes (BSPB 2010 \& $20 \mathrm{II}$ ). There is also a Common Bird Monitoring scheme that operates at the national level, covering over 100 study plots across the country. It provides data for the two most common raptors, i.e. Buzzard Buteo buteo and Kestrel Falco tinnunculus (Spasov 2008, Hristov 20II).

Information on the rest of the breeding raptors is sporadic and localised. The monitoring of migrating birds is concentrated mainly in the eastern part of the county, along the Black Sea where the Via Pontica bird migration route is situated. It covers the majority of soaring birds, most of which are raptors (Profirov I987, Michev et al. 20 I I). Autumn migration studies cover all raptors species passing over the migration watchpoints. For some regions, such as the Burgas area, there is a long-term set of data for migrating birds of prey (BSPB 2005).

The Atlas of Breeding Birds in Bulgaria covers all breeding or possibly breeding raptor species. It was published in 2008 and is foreseen to be updated every 10 years (IANKOV 2007).

The wintering raptor populations have been studied for a couple of years, but only the lowland part (up to $600 \mathrm{~m}$ a.s.l.) of Bulgaria has been covered (Nikolov et al. 2006). All raptors are recorded during the International Waterbird Census (IWC) that takes place every year in January. This monitoring scheme has been implemented for more than 20 years and has good number of records on raptors wintering near all large wetlands and rivers (over 200; Kostadinova \& Dereliev 200i).

There are regional studies of some owl species as well, but they are not covered by comprehensive monitoring activities (e.g. Shurulinkov \& Stoyanov 
2006, Shurulinkov et al. 2007).

Monitoring schemes implemented by BSPB are well coordinated. There is certain cooperation and exchange of information between the BSPB and other NGOs, but no coordination between all players at the national level has been established as yet. In order to facilitate the BSPBs network of researchers and fieldworkers scattered across the country, a new on-line GIS database has been established. It can be accessed only by staff members and expert fieldworkers, but there is a website for data gathering (www. BulgariaBirdQuest.org) that is publicly available. It is part of the "Worldbirds.org" project of BirdLife International. There are over 50 projects focused on research, monitoring and conservation of raptors in Bulgaria (Appendix 1).

\section{Key species and key issues}

\subsection{Key species}

The key species of raptors covered by comprehensive monitoring schemes are Imperial Eagle Aquila heliaca, White-tailed Eagle Haliaeetus albicilla, Egyptian Vulture Neophron percnopterus, Griffon Vulture, Black Vulture Aegypius monachus, Saker Falcon Falco cherrug and Red-footed Falcon $F$ vespertinus. Information on their distribution, numbers, breeding success, productivity, diet, movements etc. is gathered on annual basis. All these species have unfavourable conservation status at the national level, while some of them are also globally threatened.

The population of the Imperial Eagle indicates a slight increase in the last decade (IANKov 2007). New studies show that more than 30 pairs are breeding in the European part of Turkey and support the increase in the population of the species in Bulgaria up to 24 pairs in 2013 (19 were present in 2008; Demerdzhiev et al. 20II).

No occupied nests of the Saker Falcon were registered last years, but the number of observations is increasing, which gives a good perspective for the future return of the species as a breeder in Bulgaria. For the 2006-2010 period, Saker Falcons were registered in a maximum of nine territories with possible 1-2 breeding pairs, but without any direct evidence of any occupied nest (IANKOV 20IO).

One of the European's most threatened species, the Egyptian Vulture, has gone through a severe decline (more than 50\%) during the last decade in Bulgaria, reaching only 29 pairs in 2012 despite all the efforts by BSPB (V. Dobrev pers. comm.). Facing many challenges, the species has reached its population minimum with less than 80 pairs in the Balkans (VeLEVsKi et al. in prep.).

The Griffon Vulture population is increasing rapidly with more than $100 \%$ population increase in the last 10 years. The apparent increase is a result of the improved carrying capacity of the environment and the hard efforts of several NGOs working in the Eastern Rhodopes as well (Demerdzhiev et al. in prep.). The first releases under the restocking programme for the species outside the Rhodopes were carried out in the last 5 years (GREen Balkans 20Io).

Despite the frequent observations of Black Vultures in Bulgaria, the only vital colony of the species in the Balkans breeds in Dadia Forest reserve in Greece. The improved carrying capacity of the environment in Bulgaria and the absence of many threats in the last few years are good prospects for future recolonization of the species in our country.

A good example of natural recolonization is the increased numbers in the White-tailed Eagles nesting in Bulgaria. The last decade has turned this almost forgotten species into a common visitor along all the biggest dams and rivers in Bulgaria, reaching more than 20 breeding pairs and still increasing.

The Red-footed Falcon is one of the species known as most sensitive to intensive farming. Abundant in the past, nowadays the species is almost extinct from the Bulgarian avifauna. The colonies discovered recently give a hope that the species will recover its numbers from the past, despite the many threats and the implementation of the EU Common Agriculture Policy (BSPB 20II).

Since 2008, BSPB implement satellite tracking programmes for Imperial Eagle (22 juveniles have been tagged so far), White-tailed Eagle (2 juv.) and Egyptian Vulture (6 juv.). Meanwhile, the Green Balkans has tagged Imperial Eagle (10 juv.; ZHelev et al. 2009, Gradev et al. 20 I I), Lesser Spotted Eagle A. pomarina (2 ind.), Long-legged Buzzard B. rufinus (1 ind.), Egyptian Vulture (1 ad., 1 subad. and 1 juv.; Gradev et al. 20 I 2), Griffon Vulture (6 subad. and 14 juv.). Important information on the migration routes and wintering grounds of the Egyptian Vulture was gathered through the satellite telemetry. Chad and Sudan were proved as main wintering areas for the Bulgarian population.

\subsection{Key issues (threats) addressed by monitoring for raptors in Bulgaria}

Main threats for the raptors in Bulgaria are similar to those in other European countries and are related to habitat loss, unnatural mortality and disturbance. The 
electrocution had previously been underestimated as a threat for raptors, but recent studies and satellite tracking of Imperial Eagles have proved that mortality, especially among juvenile birds, is significant (D. DemerdZhiev pers. comm.).

The poisoning has always been an issue, but the conflict between pigeon fanciers and the actively hunting raptors seems to be one of the main problems. Poisonous baits for Wolf Canis lupus and Golden Jackal $C$. aureus are the main threat to scavengers, while unintentional pesticide poisoning also has a negative impact on raptor populations.

In the last 10 year, habitat loss has been taking place at a greater speed than in the 1980s and 1990s. Direct payments within the framework of the European Union's RDP/CAP are the main driving force for the destruction of foraging habitats (grasslands) (Demerdzhiev et al. in print). Construction of wind farms and solar panels also lead to effective habitat loss, as well as to increased mortality among raptors due to collisions with turbine blades.

Disturbance and nest robbery is still a threat factor for the raptor populations in Bulgaria. Illegal taking of fledglings for falconry is one of the main limiting factors for some raptors such as the Saker Falcon, which is on the brink of extinction (IANKOV et al. 2013). In recent years, it became clear that persecution is an issue, especially for rare birds of prey that are a highly desired trophy for local and foreign taxidermists. Game keepers are also taking part.

BSPB has established partnerships with several countries in conjunction with the work concerning the following species: Imperial Eagle (Hungary, Turkey, Macedonia, Sudan), Saker Falcon (Hungary, Slovakia, Romania), Egyptian Vulture (Turkey, Greece, Macedonia, Albania, Ethiopia, Sudan, Chad, Syria, Oman), Griffon Vulture (Greece, Macedonia, Serbia, Israel), Black Vulture (Greece), White-tiled Eagle (Romania, Germany), Red-footed Falcon (Hungary). Migrating species are of great importance to international cooperation and our efforts will be aimed at their protection in Bulgaria and the countries with the species' flyway, stopover sites and wintering grounds (ANGELOV et al. 2012).

\section{Strengths and weaknesses}

The main strengths of the monitoring schemes for raptors in Bulgaria are the good set of data for priority species, experienced fieldworkers and good knowledge regarding important areas for raptors.

Weaknesses are related to the lack of capacity to cover most of the common raptors and insufficient/ irregular funding of the monitoring schemes. The fact that the gathered data are not used by authorities is also an important issue that has led to inadequate Environmental Impact Assessments and lack of protection of the raptors' habitats.

The main gaps in monitoring for raptors in Bulgaria are related to the lack of coverage of the majority of diurnal species that are not very common but at the same time not very rare, such as the Lesser Spotted Eagle, Short-toed Eagle Circaetus gallicus, Booted Eagle $A$. pennata and Peregrine Falcon F peregrinus. The same issues hold true for owls as well. Some regions are not well known due to the smaller number of local fieldworkers, hence more resources are needed for their survey and monitoring.

International cooperation would be valuable in lobbying for the implementation of raptor-friendly agricultural practices. Exchange of information about best agricultural practices designed for the raptors' benefit would also be useful. Remote/GIS monitoring of priority habitats and sites (SPAs) through satellite imagery or other contemporary methods would support the evaluation and prioritisation of conservation efforts for raptors in Bulgaria.

\section{Priorities, capacity-building}

Different economic sectors certainly do influence raptor populations, but there are no quantitative data to prove/illustrate that impact. That is why establishment of monitoring schemes that measure the impact of wind farms, power lines, agricultural practices, infrastructural development etc. on raptor populations will be one of the BSPB's priorities for the coming years.

It is important to incorporate raptor monitoring standards into SPAs Management Plans. BSPB will provide the necessary support to the state authorities on this issue.

State funding for suitable operation of the National Biodiversity Monitoring System and birds of prey monitoring activities is crucial for adequate protection of species and their habitats.

Training of fieldworkers, especially national parks' staff members, regional environment and water inspectorates and NGO volunteers, is a constant task that needs special attention and efforts.

\section{Povzetek}

Glavni protagonisti pri vsedržavnem raziskovanju in monitoringu ptic roparic v Bolgariji so od leta 1990 predvsem naravovarstvene nevladne organizacije. Še 
posebno dejavni med njimi sta Bolgarsko društvo za zaščito ptic (BSPB) in Zeleni Balkan, ki se posvečata najbolj ogroženim ujedam $\mathrm{v}$ državi. Ključne vrste, preučevane $\mathrm{v}$ okviru celostnega monitoringa, so kraljevi orel Aquila heliaca, belorepec Haliaeetus albicilla, egiptovski jastreb Neophron percnopterus, beloglavi jastreb Gyps fulvus, rjavi jastreb Aegypius monachus, sokol plenilec Falco cherrug in rdečenoga postovka $F$ vespertinus. Informacije o njihovi razširjenosti, številu, gnezditvenem uspehu, produktivnosti, prehrani in premikih se zbirajo na letni ravni. Tudi redni monitoring kanje Buteo buteo in postovke $F$. tinnunculus poteka na državni ravni, in sicer v okviru monitoringa pogostih vrst. Razširjenost vseh ptic roparic je bila preučevana za potrebe Atlasa bolgarskih gnezdilk. Sodobne metode satelitske telemetrije so razkrile pomembne vidike ogroženosti ter premikov orlov in jastrebov znotraj države in prek meja. Poglavitne grožnje za ptice roparice v Bolgariji so izguba habitata, nenaravna smrtnost in vznemirjanje. Glavne vrzeli v njihovem monitoringu so povezane $\mathrm{z}$ nezadostno pokritostjo večine ujed in sov. Sicer pa se razvija tesno mednarodno sodelovanje $\mathrm{v}$ povezavi $\mathrm{z}$ delom, posvečenim kraljevemu orlu ter egiptovskemu in beloglavemu jastrebu. Vsekakor pa je treba nujno pospešiti sodelovanje $\mathrm{v}$ zvezi $\mathrm{z}$ drugimi vrstami ptic roparic in lobiranje za roparicam prijazno kmetijstvo in izboljšavo nekaterih gospodarskih panog.

\section{References}

Akumarev, V., Myumyun, S. \& Dyulgerova, S. (2012): Survey on the Egyptian Vulture population in Asia Minor, Turkey. Project Report. - Bulgarian Society for the Protection of Birds, Sofia.

BSPB (2005): Observation of autumn migration of soaring birds in Bulgaria in 2004 in terms of identification of bottleneck IBAs to be included in the European Ecological Network NATURA 2000. - Bulgarian Society for the Protection of Birds, Sofia. (available at http://bspb.org/article_files/127713194912.pdf.)

BSPB (2010): [Annual report for 2010.] - Bulgarian Society for the Protection of Birds, Sofia. (in Bulgarian) (available at http://bspb.org/article_files/130521434571.pdf)

BSPB (20I I): [Annual report for 2011.] - Bulgarian Society for the Protection of Birds, Sofia. (in Bulgarian) (available at http://bspb.org/article_files/133845815923.pdf)

BUNARCO (2009): List of the Birds Recorded in Bulgaria. - Acta Zoologica Bulgarica 61 (1): 3-26.

Angelov, I. (2009): [Numbers, ecology, behaviour, threats and conservation measures for the Eastern imperial eagle (Aquila heliaca) in Sliven region.] BSc thesis. - Sofia university "St. Kl. Ohridski", Faculty of Biology, Sofia. (in Bulgarian)

Angelov, I., Hashim, I. \& Oppel, S. (2012): Persistent electrocution mortality of Egyptian Vultures Neophron percnopterus over 28 years in East Africa. - Bird Conservation International 23 (1): 1-6.

Demerdzhiev, D. (20 I I): The eastern imperial eagle (Aquila heliaca heliaca, SAVIGNY, 1809) (ACCIPITRIDAE - AVES) in Bulgaria - distribution, biology, ecology, numbers and conservation measures. PhD abstract. NNHM - BAS, Sofia.

Demerdzhiev, D., Stoychev, S., Terziev, N. \& Angelov, I. (20I I): Status of the Imperial Eagle (Aquila heliaca, Savigny, 1809) in the European part of Turkey. pp. 8793 In: Proceedings of the $6^{\text {th }}$ International Conference for Conservation of the Eastern Imperial Eagle (Aquila heliaca), 5-7 September 2008, Topolovgrad, Bulgaria. Acta Zoologica Bulgarica, Suppl. 3.

Demerdzhiev, D., Dobrev, V. \& Popgeorgiev, G. (in print): Can habitat change influence territory occupancy, breeding density, and breeding success of Long-legged Buzzard population in SPA "Besaparski hills". - Acta Zoologica.

Demerdzhiev, D., Hristov, H., Dobrev, D., Angelov, I. \& Kurtev, M. (in prep.): Long-term population status, breeding parameters and limiting factors of the Griffon Vulture (Gyps fulvus) population in Eastern Rhodopes, Bulgaria.

Dobrev, V., Arkumarev, V., Bounas, T., Pappaioannou, H., Gerdzhikov, G., Dyulgerova, S., Saravia, V., Klimentova, I., \& Nikolov, S. (20I2): Preliminary survey on the Egyptian vulture breeding population in southern Albania. Project report. - Bulgarian Society for the Protection of Birds, Sofia.

Dobrev, D., Angelov, I. \& Dobrev, V. (2013): Status and conservation of vultures in Bulgaria. Bulgarian society for the protection of birds/Birdlife Bulgaria (BSPB) activities. pp. 14-15 In: AndreEvski, J. (ed.): Vulture Conservation in the Balkan Peninsula and Adjacent Regions. 10 Years of Research and Conservation. Nacionalna i univerzitetska biblioteka "Sv. Kliment Ohridski”, Skopje.

Green Balkans (2005): The Bearded Vulture - Let's recover the symbol of Bulgarian nature conservation. Balkan Vulture Action Plan (BVAP) project report. - Green Balkans, Plovdiv.

Green Balkans (2006): Activities for the Restoration of the Populations of the Black and Griffon Vultures as the First Step for the Reintroduction of the Bearded Vulture in Bulgaria. Balkan Vulture Action Plan (BVAP) project report. - Green Balkans, Plovdiv.

Green Balkans (2007): Activities for the Restoration of the Populations of the Black and Griffon Vultures as the First Step for the Reintroduction of the Bearded Vulture in Bulgaria. Balkan Vulture Action Plan (BVAP) project report. - Green Balkans, Plovdiv.

Green Balkans (20io): [Annual report for 2010.] - Green Balkans, Plovdiv. (in Bulgarian) (available at http://www. greenbalkans.org/article_files/131238069026.pdf)

Gradev, G., Matarranz, V., Dobreva, E., Popov, D., Ivanov, I., Klisurov, I., Kmetova, E. \& Vasilakis, D. (20II): First Results of the Tracking of an Eastern Imperial Eagle (Aquila heliaca) Tagged with a GPS/GSM Transmitter in Bulgaria. pp. 15-20 In: Proceedings of the $6^{\text {th }}$ International Conference for Conservation of the 
Eastern Imperial Eagle (Aquila heliaca), 5-7 September 2008, Topolovgrad, Bulgaria. - Acta Zoologica Bulgarica, Suppl. 3.

Gradev, G., García, V., Ivanov, I., Zhelev, P. \& Kmetova, E. (2012): Data from Egyptian vultures (Neophron percnopterus) tagged with GPS/GSM Transmitters in Bulgaria. - Acta Zoologica Bulgarica, Suppl. 4: 137-147.

Hristov, H. (2000): Supplementary and monitoring actions. Eastern Rhodopes project reports. BulgarianSwiss Biodiversity Conservation Programme - Bulgarian Society for the Protection of Birds, Sofia.

Hristov, I. (20II): State of common birds in Bulgaria 2005-2010. BSPB Conservation Series, Book 19. Bulgarian Society for the Protection of Birds, Sofia.

Kostadinova, I. \& Dereliev, S. (200I): Results from the Mid-winter Counts of Waterbirds in Bulgaria for the period 1997-2001. BSPB Conservation Series, Book 3. - Bulgarian Society for the Protection of Birds, Sofia.

Michev, T., Profirov, L., Nyagolov, K. \& Dimitrov, M. (20II): The autumn migration of soaring birds at Bourgas Bay, Bulgaria. - British Birds 104 (1): 16-37.

Michev, T. \& Simeonov, P. (I98 I): [Studies on the autumn migration of some waterfowl and birds of prey near Bourgas.] - Ecology, Sofia 8: 43-48. (in Bulgarian, English summary)

Mirkov, I. (2009): [Birds of Bulgaria and their researchers. Bibliography 1950-2008.] - Sofia. (in Bulgarian)

Nikolov, S., Spasov, S. \& Kambourova, N. (2006): Density, number and habitat use of Common Buzzard (Buteo buteo) wintering in the lowlands of Bulgaria. Buteo 15: 39-47.

Zhelev, P., Gradev, G., Ivanov, I., \& Georgiev, D. (2009): [Data on the Trophic Spectrum of Young Imperial Eagles (Aquila heliaca Savigny, 1809) in South Bulgaria.] - Ecologia Balkanica 1: 51-58. (in Bulgarian, English Summary)

Profirov, L. (I987): [Study on the migration dynamics of order Falconifomes in the region of Atanasovsko lake near Bourgas.] pp. 47-50 In: Anniversary national conference in biology, Sofia. (in Bulgarian)

IANKov, P. (ed.) (2007): Atlas of Breeding Birds in Bulgaria. BSPB Conservation Series, Book 10. - Bulgarian Society for the Protection of Birds, Sofia.

IANkov, P. (20I0): [Saker Falcon in Bulgaria.] - Falke 12: 500-505. (in German)

Iankov, P., Stolanov, G. \& Ragiov, D. (2013): [Action plan for the Saker Falcon (Falco cherrug Gray, 1834) in Bulgaria.] - Ministry of Environment and Water, Sofia. (in Bulgarian)

Iankov, P. \& Profirov, L. (I99i): Contemporary state of griffon vulture (Gyps fulvus Hablizl) population in Bulgaria. - Ecology 24: 44-52.

Shurulinkov, P. \& STOYANOv, G. (2006): Some new findings of Pigmy Owl Glaucidium passerinum and Tengmalm's Owl Aegolius funereus in western and southern Bulgaria. - Acrocephalus 27 (128/129): 65-68.

Shurulinkov, P., Ralev, A., Daskalova, G. \& Chakarov, N. (2007): Distribution, numbers and habitat of Pigmy Owl Glaucidium passerinum in Rhodopes Mts (S Bulgaria). - Acrocephalus 28 (135): 159-163.

Stoynov, E. \& Peshev, H. (20II): Re-introduction of
Griffon Vulture (Gyps fulvus) in Kresna Gorge of Struma River, Bulgaria. Annual Report 2010. - Fund for Wild Flora and Fauna, Blagoevgrad.

Stoynov, E. \& Peshev, H. (2012): Re-introduction of Griffon Vulture (Gyps fulvus) in Kresna Gorge of Struma River, Bulgaria. Annual Report 2011. - Fund for Wild Flora and Fauna, Blagoevgrad.

Stoynov, E. \& Peshev, H. (2013): Re-introduction of Griffon Vulture (Gyps fulvus) in Kresna Gorge of Struma River, Bulgaria. Annual Report 2012. - Fund for Wild Flora and Fauna, Blagoevgrad.

Spasov, S. (2008): State of common birds in Bulgaria. BSPB Conservation Series, Book 13. - Bulgarian Society for the Protection of Birds, Sofia.

Velevski, M., Nikolov, S., Arkumarev, V., Dobrev, V., Topi, M., Hoxha, B., Tabur, E. \& Oppel, S. (in prep.): Decrease of population size and range contraction of Egyptian Vulture in the Balkans.

Arrived / Prispelo: 27.3. 2013

Accepted / Sprejeto: 1.7.2013 


\section{APPENDIX 1 / DODATEK 1}

Most important projects dedicated to raptor conservation and monitoring in Bulgaria for the 1994-2013 period (the list is not exhaustive)

Najpomembnejši projekti, posvečeni varstvu in monitoringu ptic roparic v Bolgariji v obdobju 1994-2013 (seznam ni popoln)

\begin{tabular}{|c|c|c|}
\hline Species / Vrsta & Project title / Naziv projekta & $\begin{array}{l}\text { Implementing } \\
\text { Organisation/ } \\
\text { Izvajalec }\end{array}$ \\
\hline \multirow{3}{*}{$\begin{array}{l}\text { White-tailed Eagle } \\
\text { Haliaeetus albicilla }\end{array}$} & Let's together protect the White-tailed Eagle on the Islands of Belene & BSPB \\
\hline & Together for Danube & $\mathrm{BSPB}$ \\
\hline & Following the White-tailed Eagle & BSPB \\
\hline \multirow[t]{2}{*}{$\begin{array}{l}\text { Lammergeier } \\
\text { Gypaetus barbatus }\end{array}$} & $\begin{array}{l}\text { The Bearded Vulture - Let's recover the symbol of Bulgarian nature } \\
\text { conservation }\end{array}$ & Green Balkans \\
\hline & $\begin{array}{l}\text { Establishing a national platform and strategy for the conservation and } \\
\text { return of the Bearded Vulture - symbol of Bulgarian nature conservation }\end{array}$ & Green Balkans \\
\hline \multirow{8}{*}{$\begin{array}{l}\text { Egyptian Vulture } \\
\text { Neophron percnopterus }\end{array}$} & Urgent measures for the conservation of the Egyptian Vulture in Bulgaria & BSPB \\
\hline & $\begin{array}{l}\text { Urgent Conservation Measures for the Egyptian Vulture (Neophron } \\
\text { percnopterus) in Bulgaria (phases III, IV and V) }\end{array}$ & $\mathrm{BSPB}$ \\
\hline & $\begin{array}{l}\text { Preparation for the implementation of large-scale conservation activities } \\
\text { for the Egyptian Vulture (Neophron percnopterus): research of newly } \\
\text { identified threatening factors, colour ringing, diet study and monitoring } \\
\text { of the population in North Bulgaria }\end{array}$ & BSPB \\
\hline & $\begin{array}{l}\text { Conservation measures for the flagship bird species in the east of } \\
\text { Bulgaria: the Egyptian Vulture }\end{array}$ & $\mathrm{BSPB}$ \\
\hline & HOPE FOR THE EGYPTIAN VULTURE & $\mathrm{BSPB}$ \\
\hline & $\begin{array}{l}\text { Marking and follow-up tracking of the priority bird species: Egyptian } \\
\text { Vulture, Black Stork and Eagle Owl }\end{array}$ & $\mathrm{BSPB}$ \\
\hline & $\begin{array}{l}\text { Return of the Neophron - Urgent measures to secure the survival of } \\
\text { the Egyptian Vulture (Neophron percnopterus) in Bulgaria and Greece; } \\
\text { LIFE10NAT/BG/000152 }\end{array}$ & BSPB \\
\hline & $\begin{array}{l}\text { Capacity Building to Support the Conservation of Migratory Egyptian } \\
\text { Vultures (Neophron percnopterus) from the Western Palearctic on their } \\
\text { Wintering Grounds in Ethiopia, Sudan and Chad }\end{array}$ & BSPB \\
\hline \multirow[t]{6}{*}{$\begin{array}{l}\text { Griffon Vulture } \\
\text { Gyps fulvus }\end{array}$} & $\begin{array}{l}\text { VULTURES' RETURN - Recovery of the population of large vultures } \\
\text { in Bulgaria; LIFE08 NAT/BG/278 }\end{array}$ & Green Balkans \\
\hline & Biodiversity Conservation in Stara Planina (Kotel Mountain Area) & FWFF \\
\hline & $\begin{array}{l}\text { Recovery through Reintroduction of the Griffon Vulture (Gyps fulvus) } \\
\text { in Central Balkan National Park }\end{array}$ & BPPS \\
\hline & $\begin{array}{l}\text { Recovery of the Griffon Vulture as a nesting species in the Vrachanska } \\
\text { Planina Mountain, Bulgaria }\end{array}$ & BPPS \\
\hline & $\begin{array}{l}\text { Recovery of the Griffon Vulture (Gyps fulvus) as a Breeding Species } \\
\text { at Vrachanska Planina Mountain; Reintroduction - Following Steps - } \\
\text { Measures }\end{array}$ & BPPS \\
\hline & $\begin{array}{l}\text { Recovery through reintroduction of the Griffon Vulture in Central } \\
\text { Balkan National Park }\end{array}$ & BPPS \\
\hline
\end{tabular}


Continuation of Appendix 1 / Nadaljevanje dodatka 1

\begin{tabular}{|c|c|c|}
\hline Species / Vrsta & Project title / Naziv projekta & $\begin{array}{l}\text { Implementing } \\
\text { Organisation/ } \\
\text { Izvajalec }\end{array}$ \\
\hline \multirow{2}{*}{$\begin{array}{l}\text { Black Vulture } \\
\text { Aegypius monachus }\end{array}$} & Conservation of the Black Vulture & Green Balkans \\
\hline & Conservation of Black Vulture in the Eastern Rhodopes & Green Balkans \\
\hline $\begin{array}{l}\text { Griffon Vulture } \\
\text { Gyps fulvus }\end{array}$ & $\begin{array}{l}\text { Activities for the Restoration of the Populations of the Black and } \\
\text { Griffon Vultures as the First Step for the Reintroduction of the }\end{array}$ & Green Balkans \\
\hline \multirow{2}{*}{$\begin{array}{l}\text { Black Vulture } \\
\text { Aegypius monachus }\end{array}$} & Bearded Vulture in Bulgaria & \\
\hline & Conservation of the Large Vultures in the Eastern Rhodopes & BSPB \\
\hline \multirow{2}{*}{$\begin{array}{l}\text { Egyptian Vulture } \\
\text { Neophron percnopterus }\end{array}$} & Feeding of scavenging birds in the Eastern Rhodopes & BSPB \\
\hline & Bulgarian-Swiss Biodiversity conservation programme in the Eastern & BSPB \\
\hline $\begin{array}{l}\text { Griffon Vulture } \\
\text { Gyps fulvus }\end{array}$ & Rhodopes (Phases I and II) & \\
\hline \multicolumn{3}{|l|}{$\begin{array}{l}\text { Black Vulture } \\
\text { Aegypius monachus }\end{array}$} \\
\hline \multirow[t]{5}{*}{ vultures } & $\begin{array}{l}\text { Assessment of the potential to expand conservation of vultures in } \\
\text { Bulgaria }\end{array}$ & BSPB \\
\hline & $\begin{array}{l}\text { Development of the Programme for Actions Against Poisons and } \\
\text { Involving the State Institutions in Solving the Problem with the Use } \\
\text { of Poison Baits in Nature }\end{array}$ & FWFF \\
\hline & $\begin{array}{l}\text { Antidote Campaign and creating preconditions for the recovery of } \\
\text { vultures in SW Bulgaria as a "bridge" between the Rhodopian and } \\
\text { Macedonian vulture communities }\end{array}$ & FWFF \\
\hline & $\begin{array}{l}\text { Anti-poisoning Campaign - Development of Compensatory Programme } \\
\text { for Livestock Damages due to Predator Attacks in SW Bulgaria }\end{array}$ & FWFF \\
\hline & Against Poison (Antidote) Activities of FWFF - Sofia & FWFF \\
\hline \multirow[t]{8}{*}{$\begin{array}{l}\text { Imperial Eagle } \\
\text { Aquila heliaca }\end{array}$} & $\begin{array}{l}\text { Investigation of the Imperial Eagle (Aquila heliaca) status in the } \\
\text { "Eastern Rhodopes" and developing of recommendations for priority } \\
\text { measures for species conservation }\end{array}$ & BSPB \\
\hline & $\begin{array}{l}\text { Survey on the Imperial Eagle (Aquila heliaca) in South Bulgaria and } \\
\text { warding of sensitive nests }\end{array}$ & BSPB \\
\hline & $\begin{array}{l}\text { Mapping of nesting areas of the Imperial Eagle (Aquila heliaca) and } \\
\text { measures for their preservation }\end{array}$ & BSPB \\
\hline & $\begin{array}{l}\text { Mapping of nesting sites of Imperial Eagle and measures for their } \\
\text { conservation }\end{array}$ & Green Balkans \\
\hline & Conservation of the Imperial Eagle in Bulgaria & Green Balkans \\
\hline & Conservation of the Globally Threatened species - The Imperial Eagle & Green Balkans \\
\hline & Conservation of the Imperial Eagle & Green Balkans \\
\hline & Strandzha - Sakar - the realm of eagles & $\begin{array}{l}\text { Reconstruction } \\
\text { and } \\
\text { Development } \\
\text { Union \& BSPB }\end{array}$ \\
\hline
\end{tabular}


Continuation of Appendix 1 / Nadaljevanje dodatka 1

\begin{tabular}{|c|c|c|}
\hline Species / Vrsta & Project title / Naziv projekta & $\begin{array}{l}\text { Implementing } \\
\text { Organisation/ } \\
\text { Izvajalec }\end{array}$ \\
\hline $\begin{array}{l}\text { Imperial Eagle } \\
\text { Aquila heliaca }\end{array}$ & \multirow[t]{2}{*}{$\begin{array}{l}\text { SAVE THE RAPTORS - Conservation of Imperial Eagle and Saker } \\
\text { Falcon in key Natura } 2000 \text { Sites in Bulgaria; LIFE07NAT/BG/000068 }\end{array}$} & \multirow[t]{2}{*}{ BSPB } \\
\hline $\begin{array}{l}\text { Saker Falcon } \\
\text { Falco cherrug }\end{array}$ & & \\
\hline $\begin{array}{l}\text { Imperial Eagle } \\
\text { Aquila heliaca }\end{array}$ & \multirow{3}{*}{$\begin{array}{l}\text { Conservation activities for target species from the Birds Directive of the } \\
\text { of EU - Lesser Kestrel, Imperial Eagle, Black Vulture in their important } \\
\text { habitats in Bulgaria }\end{array}$} & \multirow[t]{3}{*}{ Green Balkans } \\
\hline $\begin{array}{l}\text { Lesser Kestrel } \\
\text { Falco naumanni }\end{array}$ & & \\
\hline $\begin{array}{l}\text { Black Vulture } \\
\text { Aegypius monachus }\end{array}$ & & \\
\hline $\begin{array}{l}\text { Lesser Kestrel } \\
\text { Falco naumanni }\end{array}$ & $\begin{array}{l}\text { Lesser Kestrel Recovery - Greater chance for Lesser Kestrel in Bulgaria; } \\
\text { LIFE11 NAT/BG/360 }\end{array}$ & Green Balkans \\
\hline \multirow{5}{*}{$\begin{array}{l}\text { Red-footed Falcon } \\
\text { Falco vespertinus }\end{array}$} & Saving the Red-footed Falcon from extinction in Bulgaria & BSPB \\
\hline & $\begin{array}{l}\text { Counteracting the Decline of the Breeding Red-footed Falcon (Falco } \\
\text { vespertinus) Population in Bulgaria }\end{array}$ & BSPB \\
\hline & $\begin{array}{l}\text { Enhance the Nesting Habitats of Globally Threatened Species: Red- } \\
\text { Footed Falcon }\end{array}$ & BSPB \\
\hline & Together for the Red-Footed Falcon & BSPB \\
\hline & $\begin{array}{l}\text { Improving the nesting conditions for the Globally Threatened Red- } \\
\text { footed Falcon (Falco vespertinus) in Bulgaria }\end{array}$ & BSPB \\
\hline \multirow{4}{*}{$\begin{array}{l}\text { Saker Falcon } \\
\text { Falco cherrug }\end{array}$} & Action plan for Saker (Falco cherrug) conservation in Bulgaria & BSPB \\
\hline & Saving the Saker Falcon (Falco cherrug) in Bulgaria & BSPB \\
\hline & Joint efforts in saving the Saker Falcon in Bulgaria & BSPB \\
\hline & $\begin{array}{l}\text { Falco cherrug B-H-R-S - Conservation of Falco cherrug in Northeastern } \\
\text { Bulgaria, Hungary, Romania and Slovakia; LIFE09NAT/HU/000384 }\end{array}$ & BSPB \\
\hline birds of prey (all species) & Survey and conservation of birds of prey in East Balkan Mountains & BSPB \\
\hline
\end{tabular}

